\title{
Precision Agriculture is Crap
}

\author{
Ed W Siatti* \\ Department of Agronomy, Brazil \\ Submission: January 11, 2017; Published: February 28, 2017 \\ "Corresponding author: Ed W Siatti, Department of Agronomy, Brazil, Email: edsiatti@me.com
}

\section{Opinion}

A few days ago, I traveled down the road to visit farmers in the southeast of Brazil and what I heard from one of them really caught my attention. While we were talking about technology and its application to agriculture, the farmer stated quite emphatically; "Precision Agriculture is crap". Wow! Immediately, after hearing it, I saw myself on a mission; It was my job there to sift through the ashes and find out what was the cause behind the bad feeling about precision agriculture and the unfavorable reaction of the farmer that I was visiting. After trying to understand his frustration and reasons behind that very negative exclamation he finally opened his tool box and told me that three years ago, after an unrelenting ag sales agent gave him a great sales pitch for a "technology package" and he made the decision to invest in precision agriculture. He had expectations of increasing efficiency, reducing costs and getting better yields. Okay, nothing wrong with that, but what I heard next was disconcerting. The farmer said "I bought a big machine, invested a huge budget to get it, acquired lots of technological resources, but never used it like I should". Then he asked me "Do you know why?" They never came back to provide the needed after sales support and service to teach us to get the most out of our investment which would have helped and improved my farming operations".

That phrase kept echoing in my mind and really put my head spinning and thinking deeper about how badly noncommitted businesses and persons can destroy a valuable term about something that has been created with other's hard work. The customer's confidence was destroyed due to their lack of commitment and not fulfilling the customer's expectations after they got their precious deal. The farmer wasn't even given a proper jump start and product training and felt their investment was worthless. The farmer added: "After several frustrated attempts trying to connect with the agent that sold me the technology we took matters into our own hands. My son got so tired of waiting that he decided to make our investment worth something by seeking help from farmers in our community. He was able to get enough information to learn how to operate the machine and get us up and running."

In short, the situation that I witnessed here has shown me that the future of farming is already here, but the real problem is the gap between farming and technology.

In short, the situation that I witnessed here has shown me that the future of farming is already here, but the real problem is the gap between farming and technology. There is an abyss between cutting-edge technology and farmers that must be closed. How to narrow and ultimately bridge that gap? For me, some tech companies are not giving proper after sale care to their customers when it comes to making them feel comfortable and familiarizing them with the technology they are selling to them. The purpose of after the sale care should be to provide knowledge, basic understanding and training, operating and breaking down the technology and transforming it in a useful tool for farmers so they can more easily face their farming challenges on a daily basis. As an industry, we could be more efficient today if we had more ag professionals and companies committed to provide a decent after-sales service and support for farmers, especially the ones that often take a while to decide to get into the technology avenue. When these farmers finally embrace it, it is very important that at the end of the day they are not so frustrated, otherwise they will never make an endorsement of precision agriculture for their counterparts and when this sad event happens, we all lose! 
This work is licensed under Creative Commons Attribution 4.0 License

DOI: 10.19080/ARTOAJ.2017.04.555640
Your next submission with Juniper Publishers will reach you the below assets

- Quality Editorial service

- Swift Peer Review

- Reprints availability

- E-prints Service

- Manuscript Podcast for convenient understanding

- Global attainment for your research

- Manuscript accessibility in different formats ( Pdf, E-pub, Full Text, Audio)

- Unceasing customer service

Track the below URL for one-step submission https://juniperpublishers.com/online-submission.php 